University of South Florida

DIGITAL COMMONS

Digital Commons @ University of

@ UNIVERSITY OF SOUTH FLORIDA

South Florida

Government and International Affairs Faculty

Publications

Government and International Affairs

2014

\title{
Class In-Formation: The Intersection of Old and New Media in Contemporary Urban Social Movements
}

Peter N. Funke

University of South Florida, pnfunke@usf.edu

Todd Wolfson

Rutgers University, twolfson@cri.rutgers.edu

Follow this and additional works at: https://digitalcommons.usf.edu/gia_facpub

Part of the International Relations Commons

\section{Scholar Commons Citation}

Funke, Peter N. and Wolfson, Todd, "Class In-Formation: The Intersection of Old and New Media in Contemporary Urban Social Movements" (2014). Government and International Affairs Faculty Publications. 120.

https://digitalcommons.usf.edu/gia_facpub/120

This Article is brought to you for free and open access by the Government and International Affairs at Digital Commons @ University of South Florida. It has been accepted for inclusion in Government and International Affairs Faculty Publications by an authorized administrator of Digital Commons @ University of South Florida. For more information, please contact digitalcommons@usf.edu. 
Class In-Formation: The Intersection of Old and New Media in Contemporary Urban

\section{Social Movements}

In:

Social Movement Studies, Volume13, Issue 3, August 2014, pp. 349-364, co-

\section{Peter Nikolaus Funke}

Department of Government and International Affairs, University of South Florida pnfunke@usf.edu

http://gia.usf.edu/faculty/pfunke/

$1-(215)$ 385-6151

Department of Government and International Affairs, University of South Florida 4202 East Fowler Avenue, CIS 1040

Tampa, FL 33620-9951

USA

\section{Todd Wolfson}

Department of Journalism and Media Studies, Rutgers University

twolfson@rci.rutgers.edu

School of Communication and Information, Rutgers University

4 Huntington St

New Brunswick, NJ 08901

USA 
During the anti-colonial struggles of the mid-1950s, the people of Algeria embraced the radio as a key instrument of their socio-political and cultural revolution. Frantz Fanon (1994) famously described how the Algerian National Liberation Front (FLN) re-appropriated the radio, changing it from a tool of French colonial domination to a weapon of resistance. As Fanon argues, 'the creation of a Voice of Fighting Algeria,' (p. 93) ${ }^{1}$ and the correspondent construction of an Algerian version of truth, put the French truth, which for so long was unchallenged, on the defensive. This counter narrative forged a new Algerian reaction to the occupying force, one that was no longer a desperate refusal but instead a creative act, defining a new anti-colonial Algeria. Thus, while in the hands of the French the radio served to further French domination, obscuring social relations and isolating 'natives' from one another, it was the FLN's re-appropriation which turned the radio into a tool of information, connection and unification, creating a new language of Algerian resistance and nationhood. ${ }^{2}$

Today, fifty years after the Algerian revolution, communications technologies are once again taking center stage in the radical social changes sweeping across North Africa and the Middle East. As uprisings percolated from Tunisia and Egypt to Libya and Yemen, people began touting the role of social media in fomenting revolution. For instance, the Wall Street Journal hailed 'Egypt's Revolution by Social Media' and others predicted the coming of 'Twitter Revolutions' and 'Facebook Warriors.' Like Fanon, these social critics see in new media technologies the capacity to quickly circumvent power structures, share stories and strategies, and mobilize people to act collectively. Converging with the hopeful analysis on the role of social media on recent revolutions, scholars have asserted that we are on the verge of a new democratic age, where flat, networked organizational structures and new forms of

\footnotetext{
${ }^{1}$ Italics in original.

${ }^{2}$ This article is collaboratively written. The author's names therefore appear in alphabetical order.
} 
participatory culture will correct historical imbalances, giving way to new avenues and possibilities for democratic social change (Shirkey, 2008)

In response to this view on the intersection of new media and society, critical analysts have countered that the social media revolution thesis is emblematic of a tendency to embody a naive cyber-optimism, wherein the internet in general, and the rise of social networking in particular, will be the solutions to global ills. In contradistinction critics such as Nugent (1995) and more recently Gladwell (2010) argued that social media has very little if any meaningful impact on activism.

While both sides of this debate make important contributions, in this article we join and advance recent arguments of social movement researchers that call for a more nuanced view on online and offline activism (e.g. Dunbar-Hester, 2009; Earl et. al. 2010; Feenberg, 2009; Van Laer, 2010). While many of these studies have focused on internet-based activism, we broaden the scope, arguing for a more complex and careful understanding of the relationship between communication and contemporary social movement in general and communication and communication mediums ('media') in particular. To the first, it is critical to build on the work of Marx (1978), Fanon (1994) and more recently Gamson (1997), Eyerman \& Jamison (1998), and Bimber et. al. (2005) in order to develop a more thorough analysis of the role of communication in the formation of collective identity and collective action writ large. ${ }^{3}$ Second, we believe this distinction between communication and communication medium is fruitful as it helps bring into focus the understudied role of communication in social movement scholarship, while suggesting a more nuanced approach to understanding the role of particular mediums as tools of struggle. In this sense, recognizing

\footnotetext{
${ }^{3}$ We conceptualize communication in collective identity formation along three overlapping practices: 1 . creating communicative spaces; 2 developing collective narratives; and 3. forging shared resistance.
} 
the necessity of communication amongst Egyptians during the Arab Spring, for instance, would be different from looking at the specific role of twitter in that moment.

In this article we focus on communication mediums and thus look at the particular roles that old and new media play for the formation of a movement powered working class in the United States of America. In the following we make three arguments. First, we hold that the shifts to a neoliberal form of capitalism and the ensued splintering of the working class (Lash \& Urry, 1987; Sites, 2007; Wacquant, 2010) is leading to a more central role for communication in class-based social movements. Second, we argue that both old (e.g. radio) and new (e.g. internet) media play a key role in creating class identity. Similar to Roy’s (2010) recent argument that folk music, as a collective activity, forges social relationships within social movements, we show how the radio and internet are utilized as participatory techniques through which poor and working class constituencies share their conditions, struggles, and build a collective sense of identity and resistance. Hence, we challenge both the denial of any meaningful impact of social media tools, while at the same time refuting the unexamined embrace of new media in the development of networked movements, specifically amongst poor and working class communities that have relatively little access to these technologies. Third, we show that the successful use of old or new media depends on important contextual questions, regarding technology access, and geographic as well as scalar aspects of a movement's constituency.

Our analysis draws on two years of fieldwork $(08 / 2008-08 / 2010)$ on the Philadelphia-based Media Mobilizing Project (MMP). ${ }^{4}$ MMP is a community-based social

\footnotetext{
${ }^{4}$ This research was made possible thanks to the support of the Social Science Research Council’s Necessary Knowledge for a Public Sphere program and its Collaborative Grant in Media and Communication, Large Grant Competition, “Alternative Media and Democratic Praxis,” (2007).
} 
movement network with regional and global ties, employing media and communications as an organizing and movement-building tool to congeal a class-based formation. Our ethnographic research focused on the organizing and media practices of MMP members, and includes twenty interviews with leaders of organizations across the broader MMP network.

In the following we first offer a set of theoretical interventions. We begin with a succinct review of New Social Movement Theory (NSM) to argue that contrary to NSM, class is still a pivotal dimension of collective identity formation. We then substantiate this claim, investigating the relationship between neoliberal capitalism, class formation, and the role of communication in movement politics. Based on these arguments, we examine the practices of MMP to argue for a more complex and 'meshed' understanding of old and new communication mediums for the formation of contemporary class identity.

\section{Social Movement Theory, Class Identity and Communications}

With the onset of what sociologists called post-industrial society, and on the heels of the exuberant movements of the 1960s, New Social Movement theorists claimed ${ }^{5}$ that the struggle for power would shift away from the realm of work to what Touraine marked as 'the setting of a way of life, forms of behavior and needs' (1988, p. 25). Based on these new socio-political cleavages, new identities would materialize other than proletariat and bourgeoisie. The study of how these new identities emerged and were able to take collective action has become a central question for social movement theorists (Snow \& Benford, 1988). In this article we build on NSM theory, as we attempt to understand how a collective class-based identity is forged through the use of media. However we have two caveats.

First, we reject the notion that class and class identity is an antiquated logic of the

5 See Touraine (1971), Habermas (1981), Laclau and Mouffe (1985), Offe (1985) Melucci (1989), and Castells (1996) among others. 
industrial era. In place of class-based identities, in most contemporary scholarship collective identity is understood in less material ways, germinating around more flexible, performative and thus hybrid categories of gender, race or sexual orientation (Castells 1996, Laclau and Mouffe 1985). While it is vital to understand these forms of collective identity, we contend that socio-economic class, as a set of material experiences that structure social life has not disappeared but rather intensified as increasing un/underemployment, shrinking middle classes, and growing economic inequalities deepened during the last thirty years (Harvey 1990 and 2005, Davis 2006, Robinson 2004). Thus, while we agree with Katznelson’s contention that it is difficult to locate class identity in the U.S. (1981), we argue that the formation of class-based identity is a pivotal and currently understudied axis for understanding local, national and global social-movement-based resistance.

Second, while social movement theory and media studies have made careful nods to one another, as the literature on framing and social movements and the study of alternative media illustrate, there has been scant research that attempts to synthesize across social movements and alternative media. This problem has begun to be rectified, particularly as research has emerged first on the Global Social Justice Movement and organizations like the indymedia movement ${ }^{6}$ and more recently as scholars attempt to understand the role of social

\footnotetext{
${ }^{6}$ Indymedia has inspired a great deal of scholarship. Some of the critical foundational texts are Kidd's examination of IMC activists and the communication commons (2003); Halleck's research on the birth of indymedia (2003); Morris’ research on the critical media-based practices of indymedia activists (2003); Juris’ focus on how indymedia activists utilize digital media to coordinate actions (2005); and Wolfson's research on the impact of the EZLN on indymedia media based practices (2012).
} 
media in the Arab Spring and Occupy Wall Street. ${ }^{7}$ While this research has begun to fill this gap, as Downing recently argued, 'the gulf between these bodies of research is to the signal disadvantage of advanced theory building and thus, ultimately damaging to the public understanding of the full dimension of democratic process' (2008: 42). We concur with this claim, and aim to synthesize social movement theory and media studies in our attempt to understand the process of forging a collective, class-based identity through old and new media.

In particular, we study the historically and contextually specific role of communication mediums (from radio to twitter) for social movement building. Along these lines, we argue for the need to distinguish between the categorical function of communication in collective identity-formation, and the more contextually specific role of communication mediums (from personal and 'old' media platforms like radio and print to new and predominately internet-based media frameworks) in movement building. This perspective on the role of both communication and communication mediums in struggle has recently begun to be explored by sociologists (Eyerman \& Jamison, 1998; Roscigno \& Danaher, 2004), focusing on the role of music on social movement politics. This is exemplified by Roy's study of the People's Songs movement of the 1930s-40 and the Civil Rights movement of the 1950s-60s. Roy argues, 'the effect of music on social movement activities and outcomes depends less on the meaning of the lyrics or the sonic qualities of the performance than on the social relationships within which it is embedded' (2010, p, 2). This contention that the 'medium is the message,' is also explored in Roscigno and Danaher's study of the labor struggles of the 1920s-30s in the American South. They argue that the ability of the radio to

\footnotetext{
${ }^{7}$ This is exemplified by a recent special issue of the Journal of Communication focused on the role of social media in the Arab Spring (2012) as well as articles on the role of social media in OWS (Juris, 2012; Mattoni, 2012).
} 
enter into people's homes and change their vision of political opportunities had a transformative effect on the political outcome of Southern textile workers. We build on this work, arguing that different communication mediums play vastly different roles in forming class based collective identity.

\section{Communication and Class: From Fordism to Neoliberal Capitalism}

The debate on the role of media as an organizing tool for social movements is often linked to discussions of the shifting global politico-economic order from Fordism to post-Fordism. While the distinction between Fordism and post-Fordism should not be overstated, the new economic system can be differentiated by the speed and mobility of capital, goods, people and ideas. New information and communication technologies are emblematic and vital for these developments (Robinson, 2004; Harvey, 2005). The fluidity of both objects and ideas has led to varied forms of analysis, including rescaling notions of state power, remapping forms of sovereignty and reconfiguring modes of subjectivity.

Building on these transformations of the political economy with its ensuing affects on the nature of class-based movements, and acknowledging that communication has always been important for class formation (Marx, 1978 Katznelson, 1981; Cohen, 1990), we argue that today communication plays an increasingly pivotal role in contemporary class formation. The increasingly atomized, isolated nature of social life as well as the apparent splintering of the working class under neoliberal capitalism (Lash \& Urry, 1987; Sites, 2007; Wacquant, 2010) makes the commonality and shared class identity between the sectors of the contemporary neoliberal working class of, for instance, taxi drivers or nurses appear less 'obvious.' This generates a need for even thicker communicative processes to form class identity across the arguably more diverse constituency of the current working class. 
To offer context, in the industrial era the generalized belief was that capital accumulation came from fixed investments and economies of scale. This led to the development of massive factories, such as the Ford River Rouge Complex outside Detroit, which employed over 100,000 people at its height in the 1930s. The logic of stable, fixed capital accumulation had social and political consequences as the industrial working class tended to toil together in large factories, mines and docks, leading to a physical and cognitive/cultural proximity, which allowed workers to share experiences and build solidarity.

Across the last forty years however, neoliberal capitalism has expanded and deepened the reach of capitalism's logic (Harvey, 1990 \& 2005; Robinson, 2004), forging a global division of labor while penetrating into what were once public sectors of society such as education and health care. These shifts have had material outcomes, changing the nature of the U.S. working class from industrial workers to service-sector workers. ${ }^{8}$ In a parallel fashion, patterns of Fordist mass consumption and mass culture are shifting to more nichelike patterns with implications for class formation. Cohen's work on the industrial workers in Chicago for example shows how in the 1920s-30s, the nation moved 'from diverse social worlds circumscribed by race, ethnicity, class, and geography to more homogeneous cultural experiences brought about by the triumph of mass culture, mass consumption, mass unionization, and mass politics' (1990, p. 8). Mixing in factories as well as following similar mass consumption patterns, generated commonality between the ethno-racially diverse working class as it allowed not only for communication to take place on the shop floor but

\footnotetext{
${ }^{8}$ We recognize that there are problems in thinking of periods, both because they elide continuity and paper over dissonance within a specific moment in time, but as Jameson (1990) argues, if we do not see patterns in history then we are forced to argue that the contemporary moment is an anarchic jumble of phenomena with no socio-historical link.
} 
'gave them more in common to talk about' (Cohen, 1990, p. 325). The communicative processes necessary for forging a class identity were aided by the industrial workers' similar shop floor and consumption experiences.

Neoliberalism on the other hand, while reinforcing mass consumption patterns and proletarianizing increasing sectors of society, is simultaneously re-introducing the fragmentation and thus disempowerment of workers along racial, geographic or skill lines that had characterized the US prior to the advent of Fordism. The current neoliberal working class is thus both expanding as new parts of the population are coming under the capitalist logic, as well as fragmenting, as the urban working class is more isolated than the industrial proletariat. The arguably more diverse modalities of neoliberal exploitation and correspondingly, the lessening of shared work and life experiences makes it more difficult to empathize as a class and to develop a class-based identity.

Thus, while sectors of the neoliberal working class find themselves in structurally analogous relations to the means of production, their manifest yet epiphenomenal differences in life and work experiences necessitates communication that run deeper and wider than during Fordism: 'deeper' in the sense of having to penetrate and deconstruct the real but superficial surface expressions of the dissimilar living and working conditions to bring forth the structural similarities of capitalist exploitation; 'wider' in the sense of having to spread out, to interlink and network the dispersed sectors of the neoliberal working class, which is no longer converging at conveyer belts, union meetings or civic clubs or societies but inhabit life worlds that appear disconnected, working in cabs and hospitals, cleaning emptied office buildings in the early morning and engaging in much more isolating 'mass consumption' patterns as people are less likely to collectively attend movie theaters, drinking establishments, bowling leagues or mutual aid societies. 
Consequently, we hold that communication serves an even more central function for generating the necessary commonality between these fractured sectors of the working class today than in the past. As such, we suggest that communication operates as an infrastructural dimension for the process of class formation, having the ability to shape and organize social relations across the fragmented landscape. In the remainder of this article and on the basis of this understanding of communication writ large, we look at the historically specific role of communication mediums such as radio or internet-based technologies.

\section{Communication-Mediums: Multimedia Platforms}

Based on our understanding of communications and class under neoliberal capitalism, we examine the ways in which new and old communication mediums are utilized for class-based social movement organizing by the Media Mobilizing Project. We show that the atomized and fractured sectors of the urban working class draw on both old and new media tools and that the choice of communication medium depends on the context. We maintain that it is this multimedia platform that allows diverse groups and alliances to come together, to begin to negotiate their everyday life, and to increasingly understand themselves as interrelated and their struggles as linked.

\section{Media Mobilizing Project}

The Media Mobilizing Project (MMP) is both a community-based media and communications infrastructure and a network of organizations across the greater Philadelphia region that aim to 'build a movement to end poverty led by the poor and working class, united across color lines. ${ }^{9}$ Established in 2005, the founders of MMP have their roots in antipoverty and poor people's organizing as well as in the participatory media making that

\footnotetext{
${ }^{9}$ http://mediamobilizingproject.org/. Accessed 7/11/2012
} 
surfaced most prominently through the Indymedia movement (Kidd, 2003; Wolfson, 2012). MMP seeks to merge these two dimensions to join class-based social movement building with a focus on the role of media and communications in binding seemingly autonomous struggles of the poor and working class communities across the greater Philadelphia community.

The Radio as a Bridge From Worker to Worker

Like Algeria in the 1950s and southern U.S. in the 1930s, today the radio is still a potent communication tool for network building and mobilization among poor and working-class constituencies. In a city like Philadelphia where over fifty percent of the population lacks affordable broadband internet access (Dailey et al., 2010), the radio is both able to reach communities that do not have access to the internet, and is well suited for specific organizing campaigns. This is exemplified by MMP and cab drivers' use of radio. While radio is principally a one-way tool and thus less prone for interactive communication, our research shows that MMP and cab drivers used both the broadcast of a radio show and the production process as a communicative device, leadership development tool and organizing instrument to further taxi driver organizing, while connecting cab drivers to broader social movement politics.

As Philadelphia lost its industrial job-base and moved toward a service sector economy, taxi drivers epitomize the city’s working class. Driven by the broader flows of global capitalism, the majority of cab drivers are immigrants, hailing from South Asia, North and West Africa and Eastern Europe, with a smaller number of U.S. born drivers. At one point cab drivers in Philadelphia were unionized. In the late1980s, however, when the major Philadelphia-based cab company declared bankruptcy, the industry reorganized and drivers were reclassified as independent contractors. In this process drivers lost their collective 
bargaining rights and became atomized contract workers. Without basic protections, the conditions for cab drivers in Philadelphia are bleak. Most cab drivers start each week in the red, as they pay fees to rent the medallion (cab license) as well as the cab, while paying for gas. Members of the Taxi Workers Alliance (TWA) estimate these costs equal \$450 a week. Because of this heavy financial burden, most cab drivers work 12-hour shifts, earning what the Philadelphia Parking Authority, which regulates the industry, estimates as an average of $\$ 4.17$ an hour. To go along with hourly earnings well-below minimum wage, workers have no sick leave, no health care benefits and no workers' compensation.

Given the difficult work conditions, in 2006 cab drivers established the Taxi Workers Alliance (TWA), in order to represent the drivers’ social and economic interests. In 2008, there were between 300-500 members in TWA out of approximately 3,000 cab drivers in the city of Philadelphia. As the President of TWA, Ron Blount explained, 'it is difficult to organize drivers because they are spread out across the city, and there is a great diversity of ethnic groups within the industry.' In contradistinction to industrial workers, cab drivers work in relative isolation and are therefore more difficult to organize. Because of the decentralized nature of the cab industry as well as the diverse ethnic makeup of cab drivers, and through a relationship with organizers at MMP, leaders of TWA recognized the importance of developing channels of communication in order for taxi drivers to both build membership and have a voice in the industry.

The process of determining which communications medium to use within TWA took time. At first MMP enlisted drivers in a digital storytelling class, and got TWA leaders computers and internet subscriptions. While this process built skills amongst a few drivers/organizers, resulting in a few short videos, it did not have an appreciable effect on organizing within TWA. At the same time, members of TWA were producing a quarterly newsletter, Waiting Times, which was an effective way of keeping drivers abreast of the 
conditions across the industry. Building on the success of Waiting Times, TWA and MMP decided that because cab drivers spend half of their day in a cab and have constant access to the radio, a radio show could be a well-suited organizing tool.

Based on this analysis, MMP joined with TWA and launched Labor Justice Radio (LJR) on September 5, 2008. LJR is a monthly hour-long radio program that airs on a community radio station WPEB, ${ }^{10}$ and as they explain, 'advocate[s] justice for all working people. ${ }^{11}$ LJR is the first radio show in the city that is 'collaboratively produced by workers and labor leaders from across the taxi, service and commercial industries. ${ }^{\text {, }}{ }^{12}$ The aim of LJR is threefold: First, MMP and TWA believed that through the production of the show, TWA members and other workers could sharpen their skills and deepen their commitment to organizing. Second, they decided to utilize the radio to reach out to new cab drivers that were not part of TWA. Finally, they saw LJR as a tool through which to forge alliances and class identities beyond the taxi industry. In this sense, MMP and TWA saw radio working in three overlapping manners: first as a leadership development tool, second as an organizing tool for cab drivers and third, as an instrument to build narrative that connects service-sector workers across the city.

To the first, LJR was conceived as a radio show that would be produced for and by workers. Organizers developed LJR through a series of trainings with cab drivers, janitors, and hotel and health care workers. In the course of the training students were taught technical skills, basic journalism and media literacy. The seven students that went through the first

\footnotetext{
${ }^{10}$ Based in West Philadelphia, WPEB reaches approximately 250,000-300,000 residents of the city.

${ }^{11}$ http://www.podomatic.com/profile/laborjusticeradio. Accessed 7/11/2012

${ }^{12}$ http://www.phillyimc.org/en/node/73672. Accessed 7/11/2012
} 
round of trainings became LJR's production team. In the three years since its launch, MMP has held four workshops, training over 20 people.

Building the critical analytic skills of people leading LJR was central to the workshop process. As the lead trainer, Sarah McKay explained, the trainings are designed to help people produce stories that either support a group's organizing or helps the listener 'make some connection that they didn’t have before.' However, the connections are not only generated through the final product. The continuous process of putting the shows together as McKay points out, helps foster 'a shared class identity' among the groups involved. Reflecting on one of the training sessions, McKay notes that most of the participants came in 'very focused on their own union and kind of putting forward the things that they were working on specifically.' Echoing Roy’s thesis (2010) that folk music is 'an activity, not just a thing,' (p. 194) for McKay, one of the key roles of the training workshops, beyond giving people practical journalism and audio production skills, was to help participants see the similarities across their different groups, and experiences. McKay explains:

[W] hat we tried to do was to create a show that was focused on issues that really affected workers but also just working people across the city... So some of the original curriculum was people going and doing interviews or stories about another group besides their own so that people would start [to] see those connections and than having conversations about the ways that ... the mainstream media covered drivers versus, like, janitors that that no one was really getting their story told and no one was getting, like, a fair shake by the media at all. So people started to kind of build an idea for a show that was more than just these collective unions. There is definitely still a strong focus on labor but we also try to talk about the budget cuts, the casino that is 
proposed to come in, housing, sometimes education.... So, I think we are working towards something that is bigger (interview, 03/2009).

Many people involved with producing LJR share this view. For example, Al Robinson, a union organizer for the Service Employees International Union SEIU 32BJ, ${ }^{13}$ pointed out that LJR played a key role in helping him to build relationships across different sectors of labor:

Labor Justice Radio allows us to blend and coexist a network with other people even though they have different issues like there are people in the clothing industry, people in the commercial industries, people in the residential industries, and now I find myself more involved with these people all the time because now we are networking and share information and finding out that we fight the same people all the time, just at different times. So our strategies become more stronger in dealing with these people and plus when they see us coming as an umbrella they give us a little more respect or listen to us a little better.

This continuous and face-to-face process of putting the shows together, as McKay points out, helps foster 'a shared class identity' among the groups involved. Much more than a local radio program, McKay argues that media and communication are tools for 'carving out more and more space' for poor and working people.

The second role MMP and TWA leaders envisioned for LJR was as an organizing tool specifically for TWA. The hope was that cab drivers would produce the show and tune into

13 SEIU 32BJ is a property service union that includes 120,000 members with primary concentration across the Northeast of the United States, but with members as far south as Florida and as far west as Montana. 
the show, and LJR would be a forum for cab drivers to collaborate and organize. This is arguably the most difficult aspect of LJR to document. Even as multiple cab drivers were trained in audio production, only one member of TWA remained a producer. While there is a problem of retention for all workers, primarily because radio production is a heavy investment in time, the lack of retention was especially acute for cab drivers, because these drivers work upwards of 60-hour weeks. Further, it has been difficult to ascertain how many cab drivers tune into LJR in Philadelphia. At the same time, as the show was focused on cab driver organizing, LJR producers became quite close to TWA leadership and the struggle of cab drivers. For this reason, TWA organizing and the cab industry is one of the most consistent themes discussed on the show.

Moreover, while it is difficult to draw direct correlation between radio and TWA organizing, since the founding of LJR, TWA has grown over two times in size to 1,000 members, and they have won important concessions around workers’ rights. Further, with TWA's consistent approach of making links to other workers, in 2011 both Philadelphia and New York's TWA, were given an official charter to be part of the AFL-CIO, even though they are not a formal union with collective bargaining rights. As Ron Blount explains 'the last time that it was issued was in the 1960s when it was granted to the United Farm Workers Union headed by the great Caesar Chavez, and one other time in the 1920s to the United Steel Workers.' In reflecting on TWA, Blount argued that the growth and success is due to the role of LJR and other communication mediums that MMP and TWA worked to develop. He explained that, 'media was a key organizing tool for TWA and was the basis of our ability to develop real worker power in Philadelphia.' While this sentiment is difficult to corroborate, Blount and other cab drivers credit LJR as playing a critical role in building the Taxi Workers Alliance while helping the fledgling workers association to organize across the multi-ethnic cab driver community. 
The final role of LJR was to build a class-based narrative that links all workers. To this end, a typical one-hour show takes on issues related to the various groups of poor and working people in the region. There are typically three to four stories per episode. The first LJR broadcast included a segment on a UNITE HERE ${ }^{14}$ boycott of Embassy Suites Hotels, a segment on recent immigration raids that targeted members of SEIU local 32BJ, and two pieces on taxi workers.

Detailing the broader focus on workers struggles, McKay explained that LJR aimed to 'share the stories and perspectives left out of mass media.' This goal was exemplified during a 2009 strike of the Philadelphia local transit workers union (TWU Local 234). Blount and other cab drivers recognized the lack of representation of workers' voices in the local mass media during the strike. In order to remedy this imbalance, Blount and other cab drivers and members of MMP went to the picket lines and interviewed workers. These recordings became the basis of both a viral video and a LJR story on the strike. A year later, LJR was recognized by the Coalition of Labor Union Women (CLUW) as well as U.S. Congressman Chaka Fattah as a critical platform and voice for poor and working people in the region, particularly because of their coverage of the TWU strike and a later nurses' strike at Temple University.

The sense of solidarity that emerged amongst cab drivers, through their relationship to the MMP network and their use of radio and other media was not sporadic but patterned, occurring multiple times throughout our research. First, in early 2009, just as LJR was developing, cab drivers came into contact with hotel workers and organizers with the local union UNITE HERE, through MMP media classes and other MMP network events. During this time, members of UNITE HERE became embroiled in a contract fight with a local high-

14 UNITE HERE is a union that represents workers in the U.S., and Canada who work in hotel, gaming, food service, manufacturing, textile and airport industries. There are approximately 250,000 active members in UNITE HERE. 
end hotel. Union organizers planned a series of actions to gain leverage in this contract fight and one of those actions was to work with MMP and other community groups to have a nonunion delegation visit the hotel and demand that management end the contract dispute. Three cab drivers including TWA president Ron Blount attended the community delegation. Following the delegation, UNITE HERE was planning for a potential strike and members of TWA pledged that they would not pick-up or drop off passengers at this local hotel during the strike. This ‘solidarity strike’ never came to fruition as UNITE HERE and hotel management worked out the dispute, however, it showed the growing sense of solidarity that developed amongst Philadelphia’s cab drivers and workers more generally.

A second example can be seen in a 2011 action in which high school students from the Philadelphia Student Union and other organizations involved in a Campaign for NonViolent Schools (CNS) organized a massive demonstration to challenge the 'school to prison pipeline,' while calling for greater funding for public education. The rally was punctuated by a march down Philadelphia’s Broad Street. At the front and back of the march were a small fleet of cabs driven by members of TWA, with signs explaining that they supported the campaign and broader push for increased funding of public education.

Across these examples, what emerged was a sense of solidarity amongst cab driverssolidarity with hotel workers, security guards, high school students and others. And importantly, as Blount and others explain, it was through their work with MMP and their use of radio and other media that cab drivers began to build this sense of unity with the broader class. This emergent sense of class-consciousness dovetails with the work of previously discussed sociologists (Eyerman \& Jamison, 1998; Roscigno \& Danaher, 2004; Roy, 2010), who argue that music generally and the radio specifically, played a critical role in the formation of collective identity in U.S.-based struggles. 
New Media, The Digital Divide and Urban Movements

While MMP utilizes 'old media' such as the radio to forge working class subjectivity, new media are also a core element of MMP's media-led movement building approach. The central component of their new media strategy is a community web portal, where MMP members and allies can upload stories, or audio/video segments. The community portal is composed of four themed sections: education, labor, housing, and general movement building. As Tim, MMP’s digital organizer explained, 'the website is meant to be a place where organizing and movement building can happen on specific issues like workers’ rights or education.’ Tim continued, 'the central web page however, is meant to link these different struggles together and show how the fight for equitable education across the region is linked to the fight of cab drivers for a union.’ This quote captures MMP’s vision to use new media to both push forward different sectors of struggle and link across what would otherwise seem like autonomous issues.

Hence, MMP's web portal is emblematic for movement building that is driven by new-media tools. New media, as the web portal indicates, lends itself well to connect and generate commonalities across a diversity of actors and issue areas as it allows for direct interactive communication through a common gateway. As such, MMP employs it to link different segments of the splintered working class in an effort to build a poor and working class-led movement. This strategy of using new media was first developed in 2007 when MMP created a video training program: Our City Our Voices (OCOV). OCOV was a collaborative project between MMP and Juntos, a local community organization dedicated to the rights of Spanish-speaking immigrants.

The idea of the Our City Our Voices project emerged during the national 2006 protests for immigrant rights. Based on the mass outpouring and a lack of immigrant voices in mainstream media, members of MMP and Juntos wanted to use Philadelphia's plan for 
developing a municipal wireless internet network as a central backbone to getting immigrants and low-wage workers to create videos and share their stories to challenge the dominant discourse. MMP and Juntos also wanted to bring Spanish-speaking immigrants into contact with students, low-wage workers and other immigrant communities. ${ }^{15}$

Supported by a grant from the Knight Foundation, OCOV trainers organized an eightweek long workshop on video production. The workshop was structured in two parts. During the first section, students were trained in video and web skills and in the second section they would go out and make videos about social and political issues. Every student in the class was also offered a desktop or laptop computer and an internet subscription. As MMP organizers explained, the aim of OCOV was to give people both the tools and skills of the digital age while developing a novel platform through the web. The OCOV workshops and its products exemplified a novel strategy for using media in building a local/regional class identity. The students of OCOV classes were selected from groups and communities that MMP had targeted as important elements of a bigger class-based movement. Students came from local immigrant communities as well as service sector unions.

OCOV's strategy of using new media and production classes to forge ties across different segments of the urban working class resulted in student-produced videos, which were used to forge tighter connections among MMP's constituent groups. The videos revealed the similarities between the various struggles of hotel workers, janitors, students, nurses or immigrants, prompting cooperation and convergence among them. As Nawala Uusiku, a housekeeper from UNITE HERE who was in both OCOV trainings pointed out to us: 'we kind of developed this sense of community. We are from different organizations but we became this community.' This community she referred to was developed both through the

\footnotetext{
${ }^{15}$ For a detailed account of organizing strategies used by immigrant communities see Das Gupta (2006), Ness (2005).
} 
creation of media as well as through the crucial process of learning how to use media. In this sense, while collective identity is forged through old and new media products, we must also continue to focus on the learning process of media production as a source of identity formation (Greenhow \& Robelia, 2009).

A further important element of OCOV workshops were the way the process of media production led to offline relationships, growing trust among people, and a shared network of struggle. As one of the OCOV trainers, Dana Perchik explained:

[E]ven these classes and workshops were working within that framework of allowing people to have the space and access to tell their own stories but also to be able to then later plug in to MMP and cover events, their own events or other people in other networks, to build alliances with each other's struggles, which was amazing to actually see happening cause I have been working with MMP for a long time and have been hearing about connections of various networks and building this giant movement and its really hard to sometimes see that and that big vision. But it was amazing because even when we were working with PSU [Philadelphia Student Union] specifically we were going covering the taxi cab workers' events and UNITE HERE and other union events, watching how everyone was actually showing up to each others work and really participating. ... I felt like it even heightened the importance of these skills and see that people can provide that for one another in their various struggles and also in their own. 
OCOV's success led organizers to design a strategy for more continuous cross-group fertilization and self-empowerment. As such, in the fall of 2008, OCOV initiated 'master classes' for those that went through the initial training cycle. As Dana explains:

The idea is to sort of form a group of people that then can be active, out filming events and documenting meetings or issues that are coming up in a timely way and sort of turning them around on the blog in a fashion that is a fast production model. ... [The goal is to] train people that then can become autonomous kind of working units. So the master class would be like the meeting point for all of those people in a regular way but in between that there would be sense that these are the activities that are going on this week or this month and who is available to cover this (interview, 06/2009).

While the OCOV project ended in 2009 because of a lack of resources, it led the organization to both recognize the importance of training in building an army of media makers that identify with one another, while also forcing MMP to understand the gravity of the digital divide. Correspondingly, MMP began to focus on new media production while also engaging and advocating around the digital divide. As MMP founder David Walker explained, 'we recognized that a majority of the folks we worked with did not have internet access... on one hand this meant we needed to focus on other media, but on the other, it led us to advocate around digital inclusion.’ Since the OCOV classes, MMP developed a digital justice coalition that put pressure on the City of Philadelphia to develop a plan around digital inclusion. Following this, MMP played a central role in applying for federal funding to address the digital divide. Currently, MMP is developing six computer centers in low-income 
communities across the city while training 700 people a year in digital literacy and basic media production. The purpose of these centers and training programs is to give people skills and access to new tools, but do this as part of a larger process that helps people to understand how their everyday struggles are linked within the wider struggle of the region's working class.

Similarly to 'old' communication mediums, analyzing the utilization of new media through our framework helps to bring out the increasing importance of communication for movement building in neoliberal capitalism. The apparent fracturing of the working class calls for communication mediums that can bring together and generate links across what might seem like unrelated issues such as unemployment or housing. MMP's web portal and projects such as OCOV are crafted to connect the different struggles and constituencies together and show the linkages between them. Bringing people online, creating videos and using web-based tools is well suited for this. At the same time, however, the reality of the digital divide prompts adjustments to internet-based movement building as a large part of the most disaffected lack the necessary access.

\section{Conclusion}

Much like the gradual adoption of the internet in working class communities across the U.S., in the 1950s Algerians were slow to adopt the radio, as it was a tool of their oppressor, the French. Over time however, as the National Liberation Front began broadcasting The Voice of Fighting Algeria, Algerians began buying radios and within a few years it became a widespread communication technology. Fanon entreats his audience to understand the radio as a technique for building identity. It was not merely the broadcast of Voice, but the act of sharing and retelling that story that became the source of collective politics. 
It is this vision of the role of the radio and web, as a participatory media technique, where members of poor and working class communities can tell and share their stories, which informs our work. More specifically, we argue for bringing a class-based focus back into the study of social movements and for a more interlinked perspective on the role of old and new communication mediums for contemporary movements. Our research shows that class-based social movement formations like the MMP network are pivotal for understanding contemporary movement struggles and that they harness both new media tools such as the internet while relying on old mediums like radio. These older mediums are vital tools for communities on the other side of the digital divide. The pervasiveness as well as variety of media combined with the economic and political precariousness faced by many contemporary urban residents suggests that networks take shape across a range of media channels. Moreover, it is not merely the final media product and its consumption that entices collective identity but the process of media production itself which can be employed to harness collective identities. Old and new media are used as participatory media techniques through which the poor and working sectors are beginning to constitute themselves as a class.

Further, we maintain that the particular context, such as a community's access to technology or the work- and life-world conditions, determines the most appropriate communication medium. Thus, while many scholars are effusive about the role of new media, in many communities old communication mediums such as the radio are more effective. In this sense, while the internet offers the ability for greater participation and many-to-many communication as well as new forms of social distribution, the vast digital divide as well as contextual factors such as work environments limit the effectiveness of these mediums for social movement politics. For contemporary poor and working class communities, a multimedia platform encompassing old, new and face-to-face communicative practices is playing a key role in urban movement building. 


\section{References}

Aglietta, M. (1979) A Theory of Capitalist Regulation: The US Experience London and New York: Verso Press.

Baucom, I. (2001) Frantz Fanon’s Radio: Solidarity, Diaspora and the Tactics of Listening Contemporary Literature. 42(1), pp. 15-49.

Bimber, B, Flanigan, A .J. \& Stohl, C. (2005) Reconceptualizing Collective Action in the Contemporary Media Environment Communication Theory. 15(4), pp. 365-388.

Boyer, R. (1990) The Regulation School. New York: Columbia University Press.

Brenner, N., \& Theodore, N. (2002) Spaces of Neoliberalism: Urban Restructuring in North America and Europe Malden: Blackwell Publishers.

Castells, M. (1996) The Rise of Network Society, The Information Age: Economy, Society and Culture Vol. 1 Cambridge MA: Blackwell.

Cleaver, H. (1979) Reading Capital Politically Austin, TX: University of Texas Press.

Cohen, L. (2008) Making a New Deal: Industrial Workers in Chicago, 1919-1939

Cambridge, Cambridge University Press 
Dailey, D., Bryne, A., Powell, A.; Karganais, J., \& Chung, J. (2010) Broadband Adoption in Low- Income Communities New York: Social Science Research Council.

Dalla Costa, M. \& James, S. (1972) The Power of Women and the Subversion of the Community Bristol: Falling Wall Press.

Das Gupta, M. (2006) Unruly Immigrants: Rights, Activism, and Transnational South Asian Politics in the United States Durham: Duke University Press.

Davis, M. (2006) Planet of Slums New York: Verso

Downing, J. (2008) Social Movement Theories and Alternative Media: An Evaluation and Critique, In Communication, Culture and Critique, 1, pp, 40-50.

Dunbar-Hester, C. (2009) “Free the Spectrum!” Activists Encounters with Old and New Media Technology New Media and Society 11.1-2 (2009): 221-240

Earl, J., Kimport, K., Prieto, G., Rush, C. \& Reynoso,K. (2010) Changing the World One Webpage at a Time: Conceptualizing and Explaining Internet Activism Mobilization: An International Journal, 15, 4, pp. 425-446.

Eyerman, R. \& Jamison, A. (1998) Music and Social Movements: Mobilizing Traditions in the Twentieth Century Cambridge: Cambridge University Press.

Fanon, F. (1994) A Dying Colonialism New York City: Grove Press. 
Feenberg, A. (2009) Critical Theory of Communication Technology: Introduction to the Special Section, In The Information Society: An International Journal, 25, pp, 77-83.

Gamson, J. (1997) Messages of Exclusion: Gender Movements and Symbolic Boundaries Gender and Society, 11(2), pp. 178-199.

Gladwell, M. (2010) Small Change: Why the Revolution Will Not Be Tweeted The New Yorker, October 10, 2010.

Greenhow, C. \& Robelia, B. (2009) Informal Learning and Identity Formation in Online Social Networks. In Learning, Media and Technology, 34(2), pp. 119-140.

Goode, J. \& Maskovsky, J. (2001) The New Poverty Studies: The Ethnography of Power, Politics and Impoverished People in the United States New York: NYU Press.

Habermas, J. (1981) New Social Movements Telos 49, pp.33-37.

Halleck, D. (2002) Hand-held Visions: The Impossible Possibilities of Community Media. New York: Fordham University Press

Hardt, M. \& Negri, A. (2004) Multitude: War and Democracy in the Age of Empire New York: The Penguin Press. 
Harvey, D. (1990) The Condition of Postmodernity: An Enquiry into the Origins of Cultural Change Malden, MA: Blackwell.

Harvey, D. (2005) A Brief History of Neoliberalism New York: Oxford University Press.

Hodos, J. (2002) Globalization, Regionalism and Urban Restructuring: The Case of Philadelphi. In Urban Affairs Review 37(3), pp. 358-379.

Howard, P. \& Parks, M. Eds. (2012) Social Media and Political Change: Capacity, Constraint and Consequences. In Journal of Communication (special issue), 62, 2.

Jameson, F. (1990) Postmodernism, or, The Cultural Logic of Late Capitalism Durham: Duke University Press.

Juris, J. (2005) The New Digital Media and Activist Networking within Anti-Corporate Globalization Movements The ANNALS of the American Academy of Political and Social Science, 597: 189-208

Juris, J. (2012) Reflections on \#Occupy Everywhere: Social Media, Public Space, and Emerging Logics of Aggregation, American Ethnologist, 39, 2, pp, 259-279

Katznelson, I. (1981). City Trenches: Urban Politics and the Patterning of Class in the United States New York: Pantheon Books. 
Kidd, D. (2003) Indymedia.org: a new communications commons. In M. McCaughey \& M.D. Ayers (Eds.), Cyberactivism: Online Activism in Theory and Practice, pp. 47-70 New York: Routledge.

Laclau, E. \& Mouffe, C. (1985) Hegemony and a Socialist Strategy: Towards a Radical Democratic Politics New York: Verso.

Lipitez, A. (1985) The Enchanted World London and New York: Verso Press.

Lukacs, G. (1971 [1923]) History and Class Consciousness Boston: MIT Press.

Marcuse, P. (2009) From Critical Urban Theory to the Right to the City City. 13(2-3), pp. 185-197

Margolis, M. \& Resnick, D. (2000) Politics as Usual: The Cyberspace 'Revolution.' Thousand Oaks, CA: Sage Publications.

Marx, K. \& Engels, F. (1978) The Marx-Engels Reader London: W.W. Norton and Company.

Massey, D. \& Denton, N. (1998) American Apartheid: Segregation and the Making of the American Underclass Cambridge: Harvard University Press. 
Mattoni, A. (2012) Beyond Celebration: Toward a More N uanced Assessment of Facebook’s role in Occupy Wall Street. Cultural Anthropology, Retrieved from http://www.culanth.org/?q=node/643

Melucci, A. (1989) Nomads of the Present: Social Movements and Individual Needs in Contemporary Society Philadelphia: Temple University Press.

Meskins-Wood, E. (1986) The Retreat from Class: A New 'True’ Socialism London and New York: Verso Press.

Morozov, E. (2011) The Net Delusion: The Dark Side of Internet Freedom New York: Public Affairs.

Morris, D. (2003) “Globalization and Media Democracy: The Case of Indymedia,” In Shaping the Network Society, (eds) Douglas Schulyer and Peter Day. Boston: MIT Press.

Ness, I. (2005) Immigrants, Unions and the New U.S. Labor Market Philadelphia: Temple University Press.

Norris, P. (2001) Digital Divide: Civic Engagement, Information Poverty, and the Internet Worldwide Cambridge: Cambridge University Press.

Nugent, D. (1995) 'Northern Intellectuals and the EZLN.’ Monthly Review, 47, 3 July/August, pp. 124-138. 
Offe, C. (1985) New Social Movements: Challenging the Boundaries of Institutional Politics Social Research, v. 52(4), pp. 817-867

Robinson, W. (2004) Theory of Global Capitalism: Production, Class and State in the Transnational World Baltimore: Johns Hopkins.

Roscigno, V. J. \& Danaher, W. F. (2004) The Voice of Southern Labor: Radio, Music, and Textile Strikes, 1929-1934 Minneapolis: University of Minnesota Press.

Roy, W. G. (2010) Reds, Whites, and Blues: Social Movements, Folks Music and Race in the United States Princeton: Princeton University Press.

Shirkey, C. (2008) Here Comes Everybody: The Power of Organizing Without Organizations New York: Penguin Press.

Sites, W. (2007) Contesting the Neoliberal City: Theories of Neoliberalism and Urban Strategies of Contention. In H. Leitner, J. Peck, E. Shepperd (Eds.), Contesting Neoliberalism: Urban Frontiers, pp. 116-138 New York: The Guilford Press.

Smith, N. (1996) The New Urban Frontier: Gentrification and the Revanchist City New York: Routledge.

Snow, D.A. \& Benford, R.D. (1988) Ideology, Frame Resonance and Participant Mobilization International Social Movement Research 1, pp. 197-217. 
Standing, G. (2011) The Precariat: The New Dangerous Class. Bloomsbury: USA.

Thompson, E.P. (1966) The Making of the English Working Class. London: Vintage.

Touraine, A. (1971) Post-Industrial Society Tomorrow’s Social History: Classes, Conflicts and Culture in a Programmed Society New York: Random House.

Touraine, A. (1988) Return to the Actor: Social Theory in Postindustrial Society Minneapolis: University of Minnesota Press

Lash, S. \& Urry, J. (1987) The End of Organized Capitalism Madison: University of Wisconsin Press.

Van Laer, J. (2010) Activists Online and Offline: The Internet as an Information Channel for Protest Demonstrations, Mobilization: An International Journal, 15, 3, pp. 347-366.

Wacquant, L. (2010) Crafting the Neoliberal State: Workfare, Prisonfare and Social Insecurity Sociological Forum. 25(2), pp. 197-220.

Wolfson, T. (2012) From the Zapatistas to Indymedia: Dialectics and Orthodoxy in Contemporary Social Movements, Communication, Culture and Critique, 5, 2, pp 149-170. 